\title{
Book Review: Sustainable Shipping in a Changing Arctic
}

\author{
Christian T. K.-H. Stadtländer* \\ Independent Researcher, St. Paul, MN, United States
}

Keywords: Arctic governance, Arctic marine environment, circumpolar shipping routes, climate change, ecosystem protection, international treaties, law of the sea, sustainable shipping

\author{
A Book Review on \\ Sustainable Shipping in a Changing Arctic \\ Lawrence P. Hildebrand, Lawson W. Brigham, Tafsir M. Johansson (Cham: Springer International \\ Publishing AG), 2018, 486 pages, US\$179.00 (Hardcover), ISBN: 978-3-319-78424-3
}

OPEN ACCESS

Edited and reviewed by: Rob Harcourt,

Macquarie University, Australia

*Correspondence:

Christian T. K.-H. Stadtländer

ctkstadtlander@msn.com

Specialty section:

This article was submitted to

Marine Affairs and Policy,

a section of the journal

Frontiers in Marine Science

Received: 08 November 2019

Accepted: 12 December 2019

Published: 15 January 2020

Citation:

Stadtländer CTK-H (2020) Book

Review: Sustainable Shipping in a

Changing Arctic.

Front. Mar. Sci. 6:799.

doi: 10.3389/fmars.2019.00799
The northern polar region (the "Arctic," sometimes dubbed the "Far North") has fascinated humans throughout history. This is well-documented in journals of whaling ship crews and explorers, as well as in writings of scholars and novelists (Schulz, 2017). Although it is a remote, cold, and seemingly inhospitable place on earth, we appreciate today the Arctic as a terrain of natural beauty with enormous biodiversity (flora and fauna) (Arctic Council, 2017), indigenous populations with over 40 ethnic groups (Arctic Centre, 2018), and a richness of natural resources (e.g., oil, gas, minerals, fish) [National Ocean Economics Program (NOEP), 2017].

In recent years, the Arctic has become an area for extensive circumpolar shipping plans as climate change lead to a recession (i.e., a decline in thickness and extent) of sea ice cover around the northern polar region [National Snow and Ice Data Center (NSIDC), 2019]. Various Arctic shipping routes linking the Pacific and Atlantic oceans are being established or further developed, including the Northwest Passage, the Northern Sea Route, the Transpolar Sea Route, and the Arctic Bridge Route (see Figure 1). These routes provide a more direct and potentially faster shipping of goods between ports in Europe, North America, and Asia.

Navigating the Arctic region is now a real possibility not only with ice breakers, but also during the summer-fall open-water seasons with commercial and pleasure ships (Aksenov et al., 2017; Murphy, 2018). Terms such as "The Emerging Arctic" [Council on Foreign Relations (CFR), 2014] or "The New Arctic" [Institute for the Study of Diplomacy (ISD), 2018] are now being used to describe this part of the world, especially when it comes to economic prospects, territorial claims, and expanded forms of governance, defense and security issues, Arctic Ocean shipping and fishing control, and access for scientific exploration. In short, the Arctic has become an area of great geo-political, geo-economic, and geo-ecological interest. However, scientists and environmental advocates expressed serious concerns that commercial and other vessel traffic in the Arctic will cause disturbances such as noise and air pollution, vessel discharges, the risk of oil spills, vessel strikes with marine mammals, and the introduction of non-native species (Hauser et al., 2018; Stevenson et al., 2019).

A recently published book entitled Sustainable Shipping in a Changing Arctic (Hildebrand et al., 2018) addresses many of these issues in great detail. The book is Volume 7 in the series of WMU (World Maritime University) Studies in Maritime Affairs. The WMU was established in 1983 by the International Maritime Organization (IMO), an agency of the United Nations.

The editors of the book (Hildebrand et al., 2018) assembled a group of experts in marine affairs and policy who contributed a total of 23 chapters, distributed to 7 parts, in which they described the issues, challenges, and opportunities of Arctic shipping. More specifically, Brigham and Hildebrand 


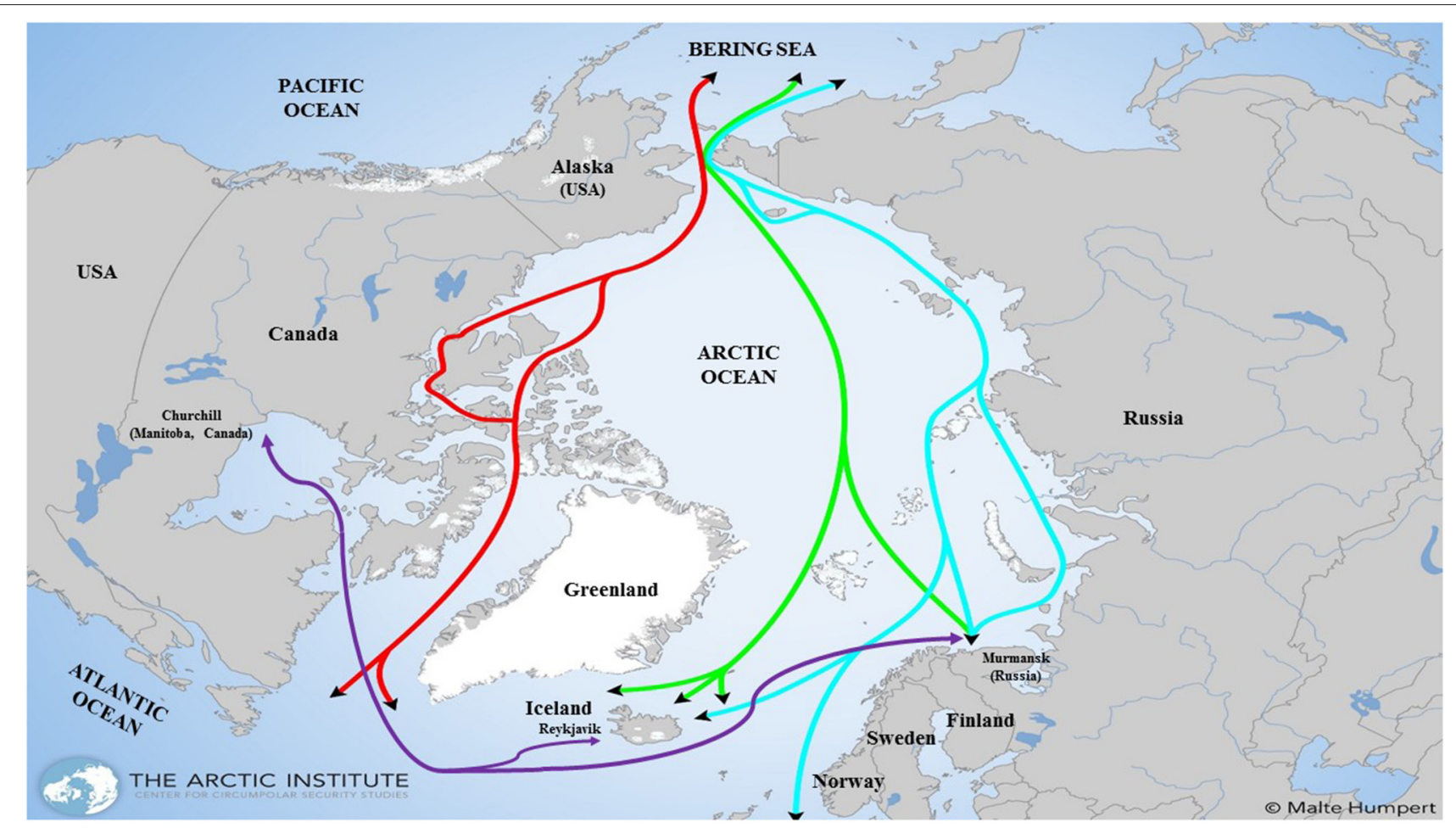

FIGURE 1 | Various arctic shipping routes that are opening up due to the reduction of Arctic Ocean ice coverage. Original image provided by Malte Humpert/THE ARCTIC INSTITUTE, Center for Circumpolar Security Studies (used with permission). Image was modified by adding labels and the purple arrow line. Red: Northwest Passage; Turquois: Northern Sea Route; Green: Transpolar Sea Route; Purple: Arctic Bridge Route.

discussed in the introductory chapter the forces that drive Arctic change and the framework that led to the IMO "International Code for Ships Operating in Polar Waters" (a.k.a. "Polar Code").

In Part I, the authors described the current IMO guidelines and recommendations related to maritime safety (e.g., ship design, construction, and equipment), operation and manning requirements (e.g., mandatory training and certification programs for ship crews), and environmental requirements (e.g., emission control and carriage of heavy fuel oil), as well as other issues suggested for future consideration. The various risks of Arctic shipping (e.g., extreme climate, potential failure of magnetic compasses, and reduced communication access) are also part of this discussion, as are the human element of making decisions in an environment of uncertainty.

Part II of the book is devoted to the monitoring and tracking of Arctic ships. The authors laid out the many challenges of Artic navigation and pointed to the opportunities of using various technologies, including navigation sonar, radar, and virtual aids, as well as automatic identification systems (e.g., satellite AIS vessel tracking). Strategies for avoidance of ship grounding are also described. The authors discussed here the disasters of six ships, including that of the crude oil tanker Exxon Valdez and the passenger ship Costa Concordia. Furthermore, there are case studies of specific ship operational limitations and detection/tracking methods used in the Canadian Arctic.
When discussing the northern polar region, one cannot leave out the issue of Arctic governance. Questions about who has separate/overlapping territorial claims, which actors (claimants, indigenous people, others) should be involved in negotiations, and what laws and regulations should be applied need all to be addressed. Haftendorn (2013) once pointed out that "In the Arctic region multilateral governance arrangements are formed by a net of political, legal, functional, and institutional structures" (p. 13). In Hildebrand et al. (2018) book, the focus of Arctic governance (in Part III) is primarily on the expanding role of joint development and sustainable governance, strategies of the $\mathrm{EU}$ and of Non-Arctic states, and issues of marine insurance and conservation of biodiversity. A case study of the legal status of Canada regarding the Northwest Passage is also provided.

The authors described in Part IV of the book new approaches to Arctic oil spill intervention, the effects of Arctic shipping on indigenous communities, and the establishment of marine protected areas in the Arctic. This is followed by a discussion about training and capacity building (Part V) and about the implications of offshore oil and gas operations in the Arctic (Part VI). Finally, the authors provided in the Conclusion section (Part VII) a well-selected collection of documents that can help readers understand current Arctic marine affairs and regulations, as well as challenges and opportunities for the future.

I found the book Sustainable Shipping in a Changing Arctic (Hildebrand et al., 2018) to be an excellent source 
of information about the various aspects of maritime Arctic operations. It is a one-of-a-kind book, published at a time when numerous forums/joint-meetings are being held to discuss these issues. This book can be useful to academics and educators, corporate sustainability professionals, government decision makers, investors, and philanthropists. It can serve as a reference book as well as a textbook. I highly recommend it to

\section{REFERENCES}

Aksenov, Y., Popova, E. E., Yool, A., and Nurser, A. J. G. (2017). On the future navigability of Arctic sea routes: high-resolution projections of the Arctic Ocean and sea ice. Mar. Policy 75, 300-317. doi: 10.1016/j.marpol.2015.12.027

Arctic Centre (2018). Arctic Indigenous Peoples. Available online at: https://www. arcticcentre.org/EN/arcticregion/Arctic-Indigenous-Peoples

Arctic Council (2017). State of the Arctic Marine Biodiversity Report: Conservation of Arctic Flora and Fauna. Available online at: https://www.caff.is/marine/ marine-monitoring-publications/state- of-the-arctic-marine-biodiversityreport

Council on Foreign Relations (CFR) (2014). The Emerging Arctic. Available online at: https://www.cfr.org/interactives/emerging-arctic\#!/emerging-arctic

Haftendorn, H. (2013). The Case for Arctic Governance: the Arctic Puzzle. Available online at: http://ams.hi.is/wp-content/uploads/2014/04/ thecaseforarcticgovernance.pdf

Hauser, D. D. W., Laidre, K. L., and Stern, H. L. (2018). Vulnerability of Arctic marine mammals to vessel traffic in the increasingly ice-free Northwest Passage and Northern Sea Route. Proc. Nat. Acad. Sci. U.S.A. 115, 7617-7622. doi: 10.1073/pnas.1803543115

Hildebrand, L. P., Brigham, L. W., and Johansson, T. M. (eds.). (2018). Sustainable Shipping in a Changing Arctic. Cham: Springer International Publishing AG.

Institute for the Study of Diplomacy (ISD) (2018). The New Arctic: Navigating the Realities, Possibilities, and Problems. Available online at: https://casestudies. any reader who has an interest in marine science and specifically in maritime Arctic shipping.

\section{AUTHOR CONTRIBUTIONS}

The author confirms being the sole contributor of this work and has approved it for publication.

isd.georgetown.edu/collections/isd-publications/products/the-new-arcticnavigating-the-realities-possibilities-and-problems

Murphy, J. (2018). Is the Arctic Set to Become a Main Shipping Route? Available online at: https://www.bbc.com/news/business-45527531

National Ocean Economics Program (NOEP) (2017). Arctic Natural Resources. Available online at: https://www.oceaneconomics.org/arctic/NaturalResources/

National Snow and Ice Data Center (NSIDC) (2019). Arctic Sea Ice News and Analysis. Available online at: https://nsidc.org/arcticseaicenews/

Schulz, K. (2017). Literature's arctic obsession. The New Yorker. Available online at: https://www.newyorker.com/magazine/2017/04/24/literatures-arcticobsession

Stevenson, T. C., Davies, J., Huntington, H. P., and Sheard, W. (2019). An examination of trans-Arctic vessel routing in the Central Arctic Ocean. Mar. Policy 100, 83-89. doi: 10.1016/j.marpol.2018.11.031

Conflict of Interest: The author declares that the research was conducted in the absence of any commercial or financial relationships that could be construed as a potential conflict of interest.

Copyright () 2020 Stadtländer. This is an open-access article distributed under the terms of the Creative Commons Attribution License (CC BY). The use, distribution or reproduction in other forums is permitted, provided the original author(s) and the copyright owner(s) are credited and that the original publication in this journal is cited, in accordance with accepted academic practice. No use, distribution or reproduction is permitted which does not comply with these terms. 